\title{
Influence of Integrated Nutrient Management for Garlic under Nilgiris Condition
}

\author{
M. Anand*, A. Sankari and B. Anita \\ Horticultural Research Station, Tamil Nadu Agricultural Univesity, \\ Ooty-643001, Tamil Nadu, India \\ *Corresponding author
}

A B S T R A C T

\begin{tabular}{|l|}
\hline Key w o r d s \\
Garlic, INM, \\
$\begin{array}{l}\text { Vegetative and } \\
\text { yield parameters. }\end{array}$ \\
\hline Article Info \\
\hline $\begin{array}{l}\text { Accepted: } \\
\text { 28 October } 2017 \\
\text { Available Online: } \\
\text { 10 December } 2017\end{array}$ \\
\hline
\end{tabular}

The present investigation was carried out during the year 2010 -2013 to study the influence of Integrated Nutrient Management module for garlic under Nilgiris condition. The experiment was conducted in Horticultural Research Station, Tamil Nadu Agricultural University, The Nilgiris. Among the nine treatments, the treatment combination of N:P:K:S 75:40:40:40 Kg/ha +5 t of FYM / ha + 2.5 t of Poultry manure $+2.5 \mathrm{t}$ of Vermicompost / ha performed better in terms of vegetative and yield characters for Garlic under Niligris condition and significantly increased the plant height $(64.11 \mathrm{~cm})$, number of of leaves $(9.0)$, leaf length $(41.25 \mathrm{~cm})$, neck thickness $(3.6 \mathrm{~cm})$, polar diameter $(3.69 \mathrm{~cm})$, equatorial diameter $(4.31 \mathrm{~cm})$, average weight of $10 \mathrm{bulbs}(227 \mathrm{~g})$. A grade bulbs $(5.20 \%)$, B grade bulbs $(2.50 \%)$, C grade bulbs $(1.57 \%)$, marketable yield $(79.38 \mathrm{q} / \mathrm{ha})$ and total yield (89.10 q/ ha).

\section{Introduction}

Garlic (Allium sativum L.) has been cultivated since ancient times all over the world especially in Asia. It ranks second in the Alliceace family. Garlic has medicinal properties and it is an important ingredient of the most spice cooking around the world. Garlic as a spice it is utilized in both fresh and dehydrated state in the food industry. It is dehydrated into different products such as flakes, slices and powders. Garlic bulbs contain allicin, colourless, odourless and water-soluble amino acids. On crushing the garlic bulbs the enzyme allinase breaks down into allin to produce allicin of which the principal ingredient is odoriferous diallyl disulpide. Garlic is grown worldwide in 14.66 lakh hectares, with a total production of 248.37 lakh tons and productivity of 16.94 tons/ha during the year 2012 as per FAO. China is the world leader in area (8.50 lakh ha) as well as in production (200.00 lakh tons), followed by India (2.02 lakh ha and 11.50 lakh tons). Other major garlic-growing countries are Egypt, Republic of Korea, Russian Federation, Myanmar, Bangladesh, USA, Argentina, Ukraine, Brazil, Spain, Ethiopia, and Iran. India ranks the second leading country in the world for garlic production (1221.88 MT) after China (NHB, 2015). In Tamil Nadu the garlic is cultivated 
in an area of 25.74 ('000 ha) with a production of 259.63 ('000mt) and productivity of $10.09 \mathrm{t} / \mathrm{ha}$.

In vegetable crops for obtaining the higher yield excessive amounts of inorganic fertilizers are applied (Steward et al., 2005). The excessive use of chemical fertilizers resulted in deficiency of nutrients other than applied and caused and decline in organic carbon in the soil (Singh et al., 2001).Organic inputs are often proposed as alternatives to mineral fertilizers. However organic inputs, crop residues and animal manures cannot meet crop nutrient demand over large areas because of the limited quantities available (Diriba Shiferaw, 2016). Intensive cropping, imbalanced fertilization and absence of application of micronutrients, less or no use of organic manures could result in the depletion of soil fertility (Palm et al., 1997). Complementary use of chemical fertilizers and organic manures has assumed great importance now days to maintain as well as sustain a higher level of soil fertility and crop productivity (Shalini et al., 2002). Considering the above results application of balanced sources of nutrients to obtain high yield and good quality in garlic. Thus, this research was concentrated more on integrated nutrient management in garlic for obtaining better quality bulbs.

\section{Materials and Methods}

The present investigation was carried out during the year $2010-2013$ to study the influence of Integrated Nutrient Management module for garlic under Nilgiris condition. The experiment was conducted in Horticultural Research Station, TNAU, The Nilgiris which is located at $11.4025^{\prime} \mathrm{N}$ Latitude, 76.735' E Longitude and at an Altitude of $2635 \mathrm{~m}$ above Mean Sea Level. The mean annual rainfall of The Nilgiris is $1632 \mathrm{~mm}$. The average maximum and minimum temperature is $26.0^{\circ} \mathrm{C}$ and $2^{\circ} \mathrm{C}$ respectively. The average relative humidity is 75 per cent. The experiment was laid out in a Randomized Block Design (RBD) with twenty seven treatments replicated thrice and treatment details are furnished in Table 1. The garlic bulbs were sown in the plot area of 12 $\mathrm{m}^{2}$ and spacing of $15 \times 10 \mathrm{~cm}$. All organic manures like Farm Yard Manure (FYM), Vermicompost (VC) and Poultry manure (PM) and bio-fertilizers viz., Azospirillum and phosphorus solubilizing bacteria each @ $5 \mathrm{~kg}$ each/ ha applied as a basal as per the treatment. $50 \% \mathrm{~N}$ applied as basal at the time of planting and remaining $50 \% \mathrm{~N}$ was applied in two equal splits during 30 and 45 days after planting. Full dose of $\mathrm{P}, \mathrm{K}$ and $\mathrm{S}$ applied at the time of planting as per the treatments. In each replication five plants were selected for recording biometrics observations on plant height $(\mathrm{cm})$, number of leaves, leaf length $(\mathrm{cm})$, leaf breadth $(\mathrm{cm})$, neck thickness $(\mathrm{cm})$, polar diameter $(\mathrm{cm})$, equatorial diameter $(\mathrm{cm})$, average weight of 10 bulbs (g). A grade bulbs (\%), B grade bulbs (2\%), C grade bulbs (1\%), marketable yield (q/ ha) and total yield (q/ ha). The data generated during the course of study was subjected to statistical analysis as prescribed by Panse and Sukhatme (2000).

\section{Results and Discussion}

The vegetative characters of garlic are very much important as they play a key role in deciding the ultimate crop yield. These parameters significantly differed among the various treatments and the results indicated that significant variation was observed among the treatments for all the characters studied and the results are presented in Table 2.

The application of different treatments had significantly influenced the vegetative growth and thus progressively increased the yield, it is mainly due to the overall treatments effect. 
The plant height ranged from 64.11 to 34.71 $\mathrm{cm}$. The highest plant height $(64.11 \mathrm{~cm})$ was noticed in $\mathrm{T}_{9}$ followed by $\mathrm{T}_{6}(62.60 \mathrm{~cm})$ and $\mathrm{T}_{2}(60.58 \mathrm{~cm})$. The increased plant height may be attributed due to accumulation of greater photosynthates leading to better growth parameters. These findings are in accordance with the findings of Nain Wal et al., (2015). Number of leaves per plant is one of the most important characters, since it has an important role in photosynthetic capacity for carbohydrate metabolism and photosynthates accumulation and partitioning. Higher number of leaves per plant were noticed in $\mathrm{T}_{9}(9.0$ nos), followed by $\mathrm{T}_{6}(8.7$ nos $)$ and $\mathrm{T}_{2}$ (8.3nos). Increase in number of leaves was seen under integrated application of inorganic and organic manures. This might be due to steady release of nutrients throughout the crop growth period. The above finding is in conformity with the reports of Farooqui et al., (2009). Higher leaf length of $41.25 \mathrm{~cm}$ was observed in $\mathrm{T}_{9}$, followed by $\mathrm{T}_{4}$ which registered $40.10 \mathrm{~cm}$ and the lowest leaf length of $25.30 \mathrm{~cm}$ was recorded in the treatment $T_{1}$. With respect to leaf width, the lowest value was recorded in the treatment $\mathrm{T}_{2}(1.31 \mathrm{~cm})$ and the highest was recorded in $\mathrm{T}_{3}(2.14$ $\mathrm{cm})$. The increase in leaf breadth is due to enhanced levels of nutrients and application of Azospirillium and Phosphorus Solubilising Bacteria enhanced the leaf length and width. Similar results were recorded by Jawadagi et al., (2012), Naruka and singh (2002) in garlic.

With regard to the neck thickness, $\mathrm{T}_{9}$ recorded highest neck thickness $(3.6 \mathrm{~cm})$ followed by $\mathrm{T}_{2}(3.1 \mathrm{~cm})$ and $\mathrm{T}_{6}(3.0 \mathrm{~cm})$. The lowest neck thickness was recorded in $\mathrm{T}_{8}(2.3$ $\mathrm{cm})$. Similarly, maximum polar diameter was recorded in $\mathrm{T}_{9}(3.69 \mathrm{~cm})$ followed by $\mathrm{T}_{6}(3.40$ $\mathrm{cm})$ and $\mathrm{T}_{4}(3.20 \mathrm{~cm})$. Similar trend was observed in equatorial diameter of garlic bulbs. Maximum equatorial diameter of bulb $(4.31 \mathrm{~cm})$ was recorded in the $\mathrm{T}_{9}$ and the lowest was recorded in the $\mathrm{T}_{2}(2.19 \mathrm{~cm})$. Sankar et al., (2005) reported that enhanced vegetative parameters might be due to the major nutrients supplied by the inorganic fertilizers would be utilized quickly by the crop and all other micro and macro nutrients available in organic manures would be released slowly. Hence, the combination of these manures helped to increase the availability of major nutrients which is being the constituent of protein and protoplasm, vigorously inducing the vegetative development of the plants.

Table. 1 Treatment details

\begin{tabular}{|c|c|}
\hline $\mathbf{T}_{1}$ & 100:50:50 kg N:P:K + FYM $20 \mathrm{t} / \mathrm{ha}$ (as per TNAU recommendation) \\
\hline $\mathbf{T}_{2}$ & 100:50:50:50 kg NPKS + FYM 20 t / ha (DOGR recommendation) \\
\hline $\mathbf{T}_{3}$ & 75:40:40:40 kg NPKS + FYM $15 \mathrm{t} / \mathrm{ha}$ \\
\hline $\mathbf{T}_{4}$ & 75:40:40:40 kg NPKS + poultry manure $7.5 \mathrm{t} / \mathrm{ha}$ \\
\hline $\mathbf{T}_{5}$ & 75:40:40:40 kg NPKS + vermicompost $7.5 \mathrm{t} / \mathrm{ha}$ \\
\hline $\mathbf{T}_{6}$ & 75:40:40:40 kg NPKS + $7.5 \mathrm{t} \mathrm{FYM} \mathrm{/} \mathrm{ha} \mathrm{+} \mathrm{poultry} \mathrm{Manure} 3.75 \mathrm{t} / \mathrm{ha}$ \\
\hline $\mathbf{T}_{7}$ & 75:40:40:40 kg NPKS + FYM $7.5 \mathrm{t} / \mathrm{ha}+$ vermicompost $3.75 \mathrm{t} / \mathrm{ha}$ \\
\hline $\mathbf{T}_{8}$ & 75:40:40:40 kg NPKS + poultry manure $3.75 \mathrm{t} / \mathrm{ha}+$ vermicompost $3.75 \mathrm{t} / \mathrm{ha}$ \\
\hline $\mathbf{T}_{9}$ & $\begin{array}{l}\text { 75:40:40:40 kg NPKS + } 5 \text { t FYM / ha + poultry manure } 2.5 \mathrm{t}+\text { vermicompost } \\
2.5 \mathrm{t} / \mathrm{ha}\end{array}$ \\
\hline
\end{tabular}


Table.2 The effect of integrated nutrient management on growth characteristics of garlic

\begin{tabular}{|l|c|c|c|c|c|c|c|}
\hline $\begin{array}{l}\text { Treatment } \\
\text { details }\end{array}$ & $\begin{array}{c}\text { Plant } \\
\text { height } \\
(\mathrm{cm})\end{array}$ & $\begin{array}{c}\text { No. of } \\
\text { leaves }\end{array}$ & $\begin{array}{c}\text { Leaf } \\
\text { length } \\
(\mathrm{cm})\end{array}$ & $\begin{array}{c}\text { Leaf } \\
\text { width } \\
(\mathrm{cm})\end{array}$ & $\begin{array}{c}\text { Polar } \\
\text { diameter } \\
(\mathrm{cm})\end{array}$ & $\begin{array}{c}\text { Equatorial } \\
\text { diameter } \\
(\mathrm{cm})\end{array}$ & $\begin{array}{c}\text { Neck } \\
\text { thickness } \\
(\mathrm{cm})\end{array}$ \\
\hline $\mathrm{T}_{1}$ & 57.36 & 7.2 & 25.30 & 1.46 & 1.64 & 2.50 & 2.8 \\
\hline $\mathrm{T}_{2}$ & 60.58 & 8.3 & 34.68 & 1.31 & 1.90 & 2.19 & 3.1 \\
\hline $\mathrm{T}_{3}$ & 59.41 & 7.9 & 33.30 & 2.14 & 2.45 & 2.71 & 2.9 \\
\hline $\mathrm{T}_{4}$ & 57.35 & 8.1 & 40.10 & 1.90 & 3.20 & 3.43 & 2.7 \\
\hline $\mathrm{T}_{5}$ & 34.71 & 7.4 & 36.56 & 2.01 & 2.15 & 2.77 & 2.4 \\
\hline $\mathrm{T}_{6}$ & 62.60 & 8.7 & 37.40 & 1.87 & 3.40 & 4.17 & 3.0 \\
\hline $\mathrm{T}_{7}$ & 59.60 & 7.4 & 33.15 & 1.71 & 2.17 & 2.69 & 2.4 \\
\hline $\mathrm{T}_{8}$ & 55.64 & 8.1 & 37.10 & 1.60 & 1.75 & 2.85 & 2.3 \\
\hline $\mathrm{T}_{9}$ & 64.11 & 9.0 & 41.25 & 1.85 & 3.69 & 4.31 & 3.6 \\
\hline $\mathrm{SEd}$ & $\mathbf{4 . 5 6}$ & $\mathbf{0 . 3 7 5}$ & $\mathbf{1 . 6 7}$ & $\mathbf{0 . 1 1}$ & $\mathbf{0 . 2 8}$ & $\mathbf{0 . 2 3 2}$ & $\mathbf{0 . 9 1}$ \\
\hline $\mathrm{Cd}(\%)$ & $\mathbf{9 . 7 1}$ & $\mathbf{0 . 7 9 6}$ & $\mathbf{3 . 7 6}$ & $\mathbf{0 . 2 1}$ & $\mathbf{0 . 5 7}$ & $\mathbf{0 . 4 9 2}$ & $\mathbf{1 . 5 8}$ \\
\hline
\end{tabular}

Table.3 The effect of integrated nutrient management on yield contributing characteristics of garlic

\begin{tabular}{|l|c|c|c|c|c|c|c|}
\hline $\begin{array}{l}\text { Treatment } \\
\text { details }\end{array}$ & $\begin{array}{c}\text { Average bulb } \\
\text { weight } \\
(\mathrm{g})\end{array}$ & $\begin{array}{c}\text { A grade } \\
\text { bulbs } \\
(\%)\end{array}$ & $\begin{array}{c}\text { B grade } \\
\text { bulbs } \\
(\%)\end{array}$ & $\begin{array}{c}\text { C grade } \\
\text { bulbs } \\
(\%)\end{array}$ & $\begin{array}{c}\text { Marketable } \\
\text { yield } \\
\left(\mathrm{q} / \mathrm{ha}^{-1}\right)\end{array}$ & $\begin{array}{c}\text { Total yield } \\
\left(\mathrm{q} / \mathrm{ha}^{-1}\right)\end{array}$ & $\begin{array}{c}\text { B:C } \\
\text { ratio }\end{array}$ \\
\hline $\mathrm{T}_{1}$ & 175.44 & 4.08 & 2.19 & 1.29 & 50.36 & 66.40 & $1: 1.58$ \\
\hline $\mathrm{T}_{2}$ & 181.00 & 4.11 & 2.59 & 1.50 & 62.70 & 79.55 & $1: 1.94$ \\
\hline $\mathrm{T}_{3}$ & 184.31 & 4.25 & 2.10 & 1.39 & 64.50 & 76.02 & $1: 2.01$ \\
\hline $\mathrm{T}_{4}$ & 204.00 & 4.55 & 2.25 & 1.47 & 68.50 & 80.45 & $1: 2.10$ \\
\hline $\mathrm{T}_{5}$ & 221.00 & 4.21 & 2.69 & 1.01 & 61.20 & 70.02 & $1: 1.80$ \\
\hline $\mathrm{T}_{6}$ & 217.50 & 5.01 & 2.70 & 1.60 & 70.10 & 81.35 & $1: 2.13$ \\
\hline $\mathrm{T}_{7}$ & 202.60 & 4.40 & 1.85 & 1.54 & 62.40 & 75.41 & $1: 1.84$ \\
\hline $\mathrm{T}_{8}$ & 205.60 & 3.79 & 2.00 & 1.27 & 60.55 & 75.08 & $1: 1.82$ \\
\hline $\mathrm{T}_{9}$ & 227.00 & 5.20 & 2.50 & 1.57 & 79.38 & 89.10 & $1: 2.35$ \\
\hline $\mathrm{SEd}$ & $\mathbf{1 1 . 0 1}$ & $\mathbf{1 . 0 1}$ & $\mathbf{0 . 8 4}$ & $\mathbf{0 . 0 7}$ & $\mathbf{0 . 5 3}$ & $\mathbf{0 . 6 7}$ & - \\
\hline $\mathrm{Cd}(0.05 \%)$ & $\mathbf{2 3 . 6 2}$ & $\mathbf{2 . 0 5}$ & $\mathbf{1 . 9 0}$ & $\mathbf{0 . 1 5}$ & $\mathbf{1 . 1 2}$ & $\mathbf{1 . 4 3}$ & - \\
\hline
\end{tabular}

The yield characters like average bulb weight (g), A grade bulbs (\%), B grade bulbs (\%), C grade bulbs $(\%)$, marketable yield (q/ha) and total yield (q/ha) were significantly influenced by the application of organic and inorganic manures and the results were presented in Table 3. The data registered on maximum average bulb weight $(227.0 \mathrm{~g})$ was found in $\mathrm{T}_{9}$ whereas the minimum average bulb weight in treatment $\mathrm{T}_{1}(175.44 \mathrm{~g})$. The size of bulb was directly influenced by the enhanced vegetative growth i.e. increase in height and number of green leaves (Kore et al., 2006; Gaiki et al., 2006). The increased availability of nutrients and production of growth promoting substances might have caused faster cell elongation and multiplication in turn increased size of the bulb. It was also reported by Kuldeep Sevak et al., (2012) and Dalal and Nandkar (2010). In the present study, maximum percentage of A grade bulbs $(5.20 \%)$, B grade bulbs $(2.50 \%)$ and C grade 
bulbs $(1.57 \%)$ was recorded in $\mathrm{T}_{9}$. Similar trend was also observed for total bulb yield per ha was recorded in the treatment $\mathrm{T}_{9}(89.10$ $\mathrm{q} / \mathrm{ha}$ ) followed by the treatment $\mathrm{T}_{6}(81.35$ $\mathrm{q} / \mathrm{ha})$ and treatment $\mathrm{T}_{4}(80.45 \mathrm{q} / \mathrm{ha})$, which were significantly superior over to rest of the treatments under study. The lowest total bulb yield per ha $(66.40 \mathrm{q} / \mathrm{ha})$ was recorded in the treatment $\mathrm{T}_{1}$.

With respect to the marketable yield highest was observed in $\mathrm{T}_{9}(79.38 \mathrm{q} / \mathrm{ha})$ followed by $\mathrm{T}_{6}(70.1 \mathrm{q} / \mathrm{ha})$ and lowest marketable yield was observed in $T_{1}(50.36 \mathrm{q} / \mathrm{ha})$. Biometric observations as well as bulb characters and yield of garlic were significantly influenced by the combined use of inorganic chemical fertilizers with organic sources of nutrients. This might be due to gradual and steady release of nutrients during the growth period as well as enhanced biological activity and proper nutrition to the crop (Vijay Kumar Singh et al., 2015 and Patil et al., 2007). The cost of garlic cultivation among the treatments includes human labour, land preparation, seed, manures, fertilizers, insecticides, irrigation, etc. were calculated on per hectare basis. Among the treatments, the highest net return was obtained in the $\mathrm{T} 9$ (1:2.35) followed by $\mathrm{T}_{6}(1: 2.13)$ from garlic cultivation. It could be concluded from the present investigation that $\mathrm{N}: \mathrm{P}: \mathrm{K}: \mathrm{S}$ $75: 40: 40: 40 \mathrm{Kg} / \mathrm{ha}+5 \mathrm{t}$ of FYM / ha $+2.5 \mathrm{t}$ of Poultry manure $+2.5 \mathrm{t}$ of Vermicompost / ha have performed better in terms of vegetative and yield characters for Garlic under Nilgiris condition

\section{References}

Dalal, L.P and Nandkar, P.B. 2010. Effect of biofertilizers macronutrients and Micronutrients on Bhendi. The Bioscan.5(2):267-269

Diriba-Shiferaw. G. 2016. Review of Management strategies of constraints in
Garlic production. The Journal of Agricultural Sciences. 2(3): 186-207.

Farooqui M A, Naruka I S, Rathore S S, Singh P P and Shaktawat, R.P.S. 2009. Effect of nitrogen and sulphur levels on growth and yield of garlic (Allium sativum L.). As. J. Food Ag-Ind. Special Issues 18-23.

Gaiki, U.R., Jogdande, N.D., Dalal, S.R., Nandre, D.R. and Ghawade, S.M. 2006. Effect of biofertilizer under reduced doses of inorganic fertilizers on growth and yield of garlic. Plant-Archives, 6(1):367-368.

Jawadagi, R.S, N. Basavaraj, B. Hemla Naik, B.N. Patil and B.B. Channappagoudar. 2012. Effect of planting geometry and organic sources of nutrients on growth, yield and quality of rabi onion $\mathrm{Cv}$. Bellary red. Karnataka J.Agric.Sci., 25(2): 236-240.

Kore, M.S., Shembekar, R.Z., Chopde, N.K., Kuchanwar, O.D., Pillewan, S.S. and Godse, S.B. 2006. Nutrient management in garlic (Allium sativum L.). J. Soils Crops, 16(2):465-468.

Kuldeep Sevak, N.M. Patel, H.S. Bhadhauria and V.R. Wankhade. 2012. Effect of Integrated Nutrient Management on growth and yield of garlic (Allium sativum L.). Advance Research Journal of Crop Improvement. 3(2): 164-166

Nainwal. R. C, D Singh, R S Katiyar, L Sharma and S K Tewari. 2015. Response of garlic to integrated nutrient management practices in a sodic soil of Uttar Pradesh, India. Journal of Spices and Aromatic Crops. 24 (1) : 33-36 (2015)

Naruka, I.S and Singh, B. 2002. Interactive effect of row spacing and cultivars on the yield and yield attributes of Garlic. Haryana. J. Hort. Sc., 31(3\&4): 262264.

Palm, C.A., Myers, R.J.K and Nandwa, S.M. 1997. Combined use of organic and 
inorganic nutrient source for soil fertility maintenance and replenishment. In: Brush et al., (Eds.). Replenishing soil fertility in Africa. Special publication No.51. Wisconsin, USA. Pp. 193-217

Panse, V. G., Sukhatme, P. V. 2000.Statistical methods for agricultural workers. Publication and Information Division of ICAR, New Delhi.

Patil. M. B., D. S. Shitole, S. B. Shinde and N. D. Purandare. 2007. Response of garlic to organic and inorganic fertilizers. J. Hort. Sci. 2(2): 130-133

Sankar, V., Veeraragavathatham, D. and Kannan, M. 2005. Post harvest storage life of Onion influenced by organic farming practices. In: Nrcg Report, National Symposium on current trends in Onion, Garlic, Chillies and Seed Spices-production, marketing and utilization November, 25-27, Rajguru Nagar, Pune. pp. 104-105.

Shalini, S.B., Channal, H.T., Hebsur, N.S.,
Dharmatti, P.R., and Srangamath, P.A. 2002. Effect of integrated nitrogen management on nutrient uptake in Knolkhol, yield and nutrient availability in the soil. Karnataka Journal of Agricultural Sciences. 15(1): 43-46.

Singh, M., Singh, V.P. and Reddy, K.S. 2001. Effect of integrated use of fertilizer nitrogen and farmyard manure or green manure on transformation of $\mathrm{N} \mathrm{P}$ and $\mathrm{S}$ and productivity of Rice-wheat system on vertisols. J. Indian society of soil science. 49: 430-435.

Stewart, M. W., Dibb, W. D., Johnston, E. A. and Smyth, J. T. 2005. The Contribution of Commercial Fertilizer Nutrients to Food Production. Agron. J. 97: 1-6.

Vijay Kumar Singh, Sangeeta Shree, Ravi Kumar, Paramveer Singh and Ravi Gopal Singh. 2015. Effect of microbial inoculants and inorganic fertilizers on growth and yield of hybrid Cabbage (Brassica oleracea L. Var. capitata). The Bio scan, 10(3): 1227-1231.

\section{How to cite this article:}

Anand, M., A. Sankari and Anita, B. 2017. Influence of Integrated Nutrient Management for Garlic under Nilgiris Condition. Int.J.Curr.Microbiol.App.Sci. 6(12): 3833-3838. doi: https://doi.org/10.20546/ijcmas.2017.612.442 